\title{
The Ottawa Field-Naturalists' Club Awards for 2005
}

\author{
Irwin M. Brodo, Christine Hanrahan, Beverly McBride, and Eleanor ZurbrigG
}

At the Club's Annual Soirée, held on 29 April 2006, at St. Basil's Church in Ottawa, awards were once again given to members, and two non-members, who distinguished themselves by accomplishments in the field of natural history and conservation, or by extraordinary activity within the Club. For the first time in several years, we had a recipient of the Anne Hanes Natural History Award, and the Mary Stuart Education Award was given for the second time. The following citations for those who received an award were read to the members and guests assembled for the event.

\section{Gillian Marston and Suzanne Deschenes - Members of the Year}

The OFNC's Member of the Year award recognizes the member(s) judged to have contributed the most to the club during the previous year. Education and Publicity Committee members Gillian Marston and Suzanne Deschenes have made stellar accomplishments over the past year in developing educational and publicity materials for OFNC, and leading a successful membership drive through publicity efforts. They have also brought their considerable computer skills to modernize the Club's photo library and displays.

Gillian and Suzanne are the driving force behind the OFNC's new photography contest which began in 2005 and is set for a second round in 2006. Meant to encourage people's appreciation of nature through photography, and to boost the club's library of digital photographs on natural themes, the first contest reaped 275 images, all of which have the potential to be used in displays or slideshows. The contest resulted in a professional, stunning slide show for the 2006 Annual Business Meeting. All these new images are now catalogued in a digital library, also developed and managed by Suzanne and Gillian. This library is the successor to the club's long-standing and well used slide collection.
Suzanne and Gillian together bring a special synergy of creativity and management skills. They further applied their talents in 2005, taking the club's new image collection to the public by designing and constructing several portable exhibits to highlight Ottawa nature, the club's activities, and to attract new members. Members and non-members alike will recall seeing volunteers staffing these exhibits at the entrance to popular nature walk areas such as the Britannia Conservation Area. They also appeared on site for various club excursions and conferences where they successfully attracted a good number of new members and caught the eye of educators. Gillian and Suzanne and the rest of the committee continue to develop more portable exhibits and to refine the design. For example, they put together a set of slide shows on different themes that can be shown at exhibits using a table-top projector or laptop computer.

Gillian and Suzanne, the club is grateful for your many special contributions during 2005. Designating you as members of the year is our way of saying "thank you"!

\section{Christine Hanrahan - George McGee Service Award}

Most successful organizations have a handful of members that devote themselves, body and soul, to the workings of the group, serving on committees, on Council, and in any way that they are needed to make the Club succeed. Christine Hanrahan is one of these people. The Ottawa Field-Naturalists' Club has benefited from her efforts and devotion for over 25 years, and we recognize these efforts with the George McGee Service Award. This award honours members who have volunteered their time to the betterment of the Club over several years. The award commemorates George McGee, who for more than three decades actively devoted much of his spare time to teaching people about birds and natural history through his talks and numerous outings.

Christine has been a member of the OFNC since the late 1970s. She has been an active member of many
Club committees, including the Fletcher Wildlife Garden Committee, Conservation Committee, Bird Committee, and Awards Committee. On top of this, she has recently coordinated the local group working on the Ontario Breeding Bird Atlas, which is now drawing to a close. Co-ordinating over a hundred volunteers for 5 years (plus an additional start-up trial year, plus the final data compilation/coordination in 2006) is no small feat. Not only was there all the coordination between Atlas headquarters and the region's 24 volunteers, which included distributing information packages, forms, CDs and other material, but also there were the annual meetings to coordinate, the annual reports to write, the articles for Trail \& Landscape, and hours and hours spent on-line writing e-mail messages and checking the data of the central database. And this is the second time Christine has done this! She was the lead 
coordinator in region 24 for the first Atlas project 20 years ago. After that she coordinated the Loggerhead Shrike survey in this area.

But our members probably know Christine best through her work on the Fletcher Wildlife Garden Committee over many years. She has diligently kept longterm and short-term lists of many of the FWG occupants and visitors (e.g., birds and butterflies). This includes preparing the current sightings board and the checklists. She has published many articles in Trail \& Landscape about the activities and happenings at FWG. She has prepared posters, many pamphlets, checklists, nesting reports, etc., if not solely, then as the main driving force. She has organized many important activities at the Centre to draw in and educate visitors. Every year she has prepared the FWG display and organized the hosting (including herself) at the National Capital Region Wildlife Festival. She has also prepared displays at other events such as the Health Canada-sponsored Environment Day.

Christine has represented the OFNC and the FWG on the National Capital Wildlife Festival Committee for many years and puts a huge amount of time into organizing workshops and conservation awards. The workshops she has organized have been on topics of great interest to the OFNC, such as Invasive Alien Species, conservation (Protecting Wild Places) and bird conservation.

Another of Christine's favourite activities is the OFNC Conservation Committee. She has participated in many committee activities and battles including, most recently, the Larose Forest issue. Here she worked on developing checklists of the flora and fauna with various specialists. She also worked for hours and hours with Ghislaine Rozon reviewing documents, preparing strategy, briefs, writing letters, attending all kinds of meetings in an effort to save the forest from develop- ment. Her work on conserving Petrie Island also had a major impact. Working with The Friends of Petrie Island, she compiled lists, wrote articles for Trail \& Landscape, organized field trips, as well as attending endless meetings, reviewing documents, and preparing OFNC responses. There have been many other conservation issues around Ottawa that have received Christine's attention and hard work, including: Moffat Farm, Montfort Woods, Nortel Woods, Leitrum wetlands, 5309 Bank Street (Tomlinson quarry) and Ferguson Forest. The list seems endless.

And who among us has not read, enjoyed and learned from Christine's many articles in Trail \& Landscape. She has published on birds, plants, habitats and a wide range of conservation issues. Her short article on snags and old $\operatorname{logs}$ is a well known, authoritative and influential document. It has been reproduced and widely distributed within the Ontario Ministry of Natural Resources and has been used and cited by people even in other parts of the world. Her article on hedgerows and their importance to wildlife is another gem and has become an important resource for ecologists. Since the OFNC has been on the Internet, Christine has been an active contributor to our website with informative and interesting material on a variety of natural history subjects.

Because Christine has also served as a knowledgeable member of the Awards Committee for a number of years, recognizing all her achievements and work with an appropriate prize "slipped through the cracks". Not until her nomination came from outside the committee by a number of members all wondering how she could have been overlooked so long could we make this presentation. The Club is therefore pleased to present Christine Hanrahan with this long overdue and welldeserved Service Award.

\section{Friends of the Carp River - Conservation Award (Non-Member)}

The OFNC Conservation Award, non-member, is given to a group or individual who has made an outstanding contribution in the cause of natural history conservation in the Ottawa Valley, with particular emphasis on activities within the Ottawa District.

The Friends of the Carp River have worked for many years to protect and restore the ecosystem of the Carp River, and this dedication makes them very worthy recipients of this award.

The Friends of the Carp River grew out of the West Carleton Township's Environmental Advisory Committee which began an extensive study of the Carp River in 1993. The organization was formed in 1997 as a citizen's group whose goal was to help restore and improve the health of the Carp River. The river has its headwaters just south of the Corel Centre and flows $42 \mathrm{~km}$ to the Ottawa River at Fitzroy Harbour, and is "the only river that flows entirely within the boundaries of the City of Ottawa". Over the years the river has suffered from shoreline erosion, siltation, flooding, low oxygen levels and subsequent loss of important wildlife habitat. Working with various groups, including landowners, businesses, government agencies and recreational users, the Friends are developing some substantial, achievable goals to continue rehabilitating the "ribbon of life", their wonderfully descriptive term for the Carp River.

Studies show that the Carp River has suffered overall degradation, including silting problems due in part to agricultural tilling practices and channelization. Shoreline erosion further contributes to siltation, which puts at risk the 40 species of fish inhabiting the river. Tributaries of the Carp River have severely degraded water quality due largely to agricultural fertilizers and animal wastes. In spring 2006, the threat of development in the floodplain could bring more problems such as future flooding as well as damaging restoration projects.

The Friends of the Carp River, an entirely volunteerrun organization, is dedicated to reversing the decline 
of the river and the Friends have already made tremendous improvements. The Friends have planted over 20000 trees and shrubs since 1997 with the help and cooperation of local landowners living along the river and many volunteers, and this will have a substantial positive impact on controlling erosion and siltation. With assistance from provincial foresters, site plans for tree planting have been created.

The Friends have worked with the City of Ottawa on its Watershed study, and gathered support from the Ottawa Stewardship Council and the Rural Clean Water Program. Their work was recognized with a Trillium Foundation grant of $\$ 50000$ to help them achieve their goal of rejuvenating the Carp River. One of their objectives for this grant was to commission a study of the river, which they did, and the Carp River Remediation Project report was prepared by consultants in April 2003.

The Friends of the Carp River have produced a pamphlet which details ways and means for landowners to achieve best management practices. The Friends are available to help steer farmers and others to specific programs, including funding, to enable them to implement improvements that benefit both landowners and the river.

The Friends have been ingenious, creative and tireless in coming up with ways to garner support for the river. Believing that an "image change" for the river was a necessary part of creating a positive public perception, they held a year-long photography contest that encouraged people to submit photos of the Carp River, and also persuaded them to look at the river as a thing

\section{Iola Price - Conservation Award (Member)}

The OFNC Conservation Award is given in recognition of a club member who has made an outstanding contribution towards protecting our natural environment. Iola Price is a very worthy recipient of this award in recognition of her effective membership in the City of Ottawa's Forest and Greenspace Advisory Committee (OFGAC) to promote conservation of trees and forests.

As the current Chair of the Ottawa Forests and Greenspace Advisory Committee, and co-chair before that, Iola provides an articulate and credible voice on issues related to conservation of the trees, forests and greenspace of our Nation's capital.

The Ottawa Forests and Greenspace Advisory Committee was established in the fall of 2001 to advise Ottawa City Council and provide a forum for citizens on issues related to trees and forests. Iola's accomplishments include reviewing OFGAC position papers before transmission to appropriate authorities, preparation of numerous written briefs and making powerful submissions to city committees. For example, Iola recently exhorted City Council at a budget planning meeting to "think of trees as green infrastructure, as essential to a well-ordered city as sewers, lighting and roads". of beauty . Winning entries were used to create a Millennium calendar, Flowing into the next Millennium: A year in the life of the Carp River, which was sold at cost and sold out in three months. The photos were also used to create sets of notecards, again sold at cost.

A benefit concert with Terry Tufts and Kathryn Briggs was held on Earth Day, 2001 to help raise funds for continued work on the river. A CD of a song, The Mighty Carp by Dan Mayo, inspired by the river and dedicated to the Friends was released in 2002.

The Friends explain that "shorelines are breeding grounds, nurseries, food sources, shelter, and hiding places for many species. Ninety per cent of all living things in a lake or river are found along the shoreline. Shorelines are effective natural filters and buffer zones, acting as the 'kidneys' for the watershed. Shorelines help to improve the quality and quantity of ground water. Polluted run-off is trapped and absorbed by the vegetation, thus protecting water quality. The complex interplay of plants, animals, land, and water combine to make the shorelines the single most important part of the river ecosystem."

The Friends have been remarkably successful in drawing the community into active involvement with the health of the river as evidenced not only by the many volunteers who turn out for tree-planting activities but by the tremendous support they have received from local businesses and granting agencies. For these reasons and more, the OFNC is very pleased to give the Friends of the Carp River this year's Conservation Award for nonmembers.

On many occasions, Iola has made a powerful and persuasive intervention during the City's planning process in support of the importance of greenspace and protection of sites of urban natural ecological significance. Her recent interventions regarding the Nepean Creek Corridor as well as her efforts for improving the criteria utilized for determining appropriate urban density development levels underscores this dedication towards the maintenance and protection of trees and greenspace in the National Capital Region (NCR).

Iola has provided recommendations to strengthen ecological provisions in urban design studies such as Riverside South Community Design and Leitrim Community Design. She spearheaded opposition to development projects such as the highly controversial Carp Ridge housing project and the Phase 2 Leitrim Wetlands development, which, if approved, would extend housing into the wetland itself.

Iola is recognized as a very effective and valuable "networker", regularly liaising with other tree and greenspace-oriented community groups operating in the NCR. This includes our Club through the Conservation Committee and Fletcher Wildlife Garden. Members of these committees wholeheartedly appreciate that Iola 
is very quick and efficient in replying to queries and in exploring issues and ideas, which helps so much when it allows one to continue one's work without delay.
Through this award, OFNC members recognize the outstanding efforts towards protecting our natural environment by one of our members - Iola Price.

\section{Macoun Field Club - Anne Hanes Natural History Award}

The Anne Hanes Natural History Award, named in honour and memory of one of the Club's most dedicated amateur naturalists, is made in recognition of a member who, through independent study or investigation, has made a worthwhile contribution to our knowledge, understanding and appreciation of the natural history of the Ottawa Valley. The award is designed to especially recognize work that is done by amateur naturalists.

The OFNC feels that there can be no more worthy recipient than the Macoun Field Club in recognition of the remarkable studies the members of the MFC have made of the Macoun Study Area in Bells Corners over a 35 year period, documenting rare plants and animals, tracking changes to plant and animal populations as well as the environment, producing and up-dating vegetation maps of the area, and much more. The MFC, sponsored jointly by the OFNC and Canadian Museum of Nature, has been a haven for youngsters interested in nature since 1948, and accepts members from grades 4 through 12.

The idea of having a special area of natural land designated as a "study area" for members of the Macoun Field Club came from the senior (high school) members, not from the adult leadership. The first study area in the Bells Corners area was actually where the Wild Bird Centre is now, but because the OMNR was cutting out the dead and dying elms at the time, they suggested an area across the road in a less disturbed site west of Moodie Drive. Within two years, the members had drawn a vegetation map of most of the 800 acres making up the site. This valuable base map was based on aerial photographs supplemented by field trips to determine what was there. There have been several versions made to keep pace with changes: 1972, 1986, 1992, and 2000. A colour version was created for the Club's web site (www.magma.ca/ rel/mfc/studyarea/msa.html).
In this way, the MFC members traced the changes that occurred in a significant part of the Ottawa Greenbelt brought on by urbanization, beaver activity, tree diseases and people. The MFC members, on their bi-weekly field trips over many years, mostly led by Rob Lee, created lists of trees (54 species), wildflowers, birds, mammals (29 species), reptiles and amphibians, and lichens (215 species). In the process, they discovered many rarities and have documented the disappearance of certain species. Their studies continue on everything from "the sand grains in the soil" to "Leatherwood Treehoppers."

Because each member is encouraged to "adopt a tree" and study its growth and health, its inhabitants in the crown, on the trunk and at its base, the MFC has amassed an amazing amount of information about seasonal fluctuations in a suburban forest system.

Much of this information has been organized on the MFC's amazing website designed and maintained by Rob Lee, but the information itself was gathered by the members. It is improbable that any urban greenspace in Canada has such a well-documented history of its flora and fauna.

Observations on the Macoun Study Area have been regularly published by the members in their annual magazine, The Little Bear, and, because of the Internet, is now readily available to the general public as well. Most important, the experience that the members have gained in doing careful field research has encouraged many past members to embark on a career in conservation biology, botany, zoology, park management or teaching.

The OFNC feels that the Macoun Field Club members have done a remarkable job, under the leadership of Rob Lee, and well deserves the Anne Hanes Natural History Award.

\section{Michael Léveillé - Mary Stuart Education Award}

The Mary Stuart Education Award was established to recognize members, non-members or organizations for their outstanding achievements in the field of natural history education in the Ottawa Region. Michael Léveillé, a science teacher at the Educarium, an Ottawa private school, is without doubt a natural history educator par excellence, and a most worthy recipient of this Award.

Michael has taught at the Educarium since 1996. His passion for nature is infectious and inspirational and is observed most keenly by his students. Michael brings an impressive background to his role as science teacher. He founded the Ottawa Paleontology Society in 1991 to advance an understanding of fossils. He has long been associated with the Canadian Museum of Nature where he created a number of popular programs, most notably the "Collector's Corner", a museum discovery centre. At the museum he worked with people of all ages, instilling an awareness of, and appreciation for, the natural world. However, there is no doubt that Michael excels at working with young people, encouraging them to be attuned to the rhythms of the natural world around them.

Michael is also an accomplished artist with a degree in Visual Arts from the University of Ottawa. His work has been exhibited at local universities, museums, as well as at the Educarium. Michael was the artist for the children's storybook series "Fergi the Frog". 
Under Michael's knowledgeable direction, in 2004 his students designed and implemented the "Macoun Marsh Project" at Beechwood Cemetery, to demonstrate how a thriving and diverse ecosystem can exist inside a large urban centre. This became one of their most ambitious and high profile projects, and is ongoing. Because the marsh was unnamed when they began working on it, they held a "Marsh Naming Contest" and encouraged neighbours and the community at large to join in. Overwhelming support led to naming it after John Macoun (1831-1920) who is buried at Beechwood. The contest, and the work done by the students, led to increased public awareness of the site and eventually resulted in the Directors of Beechwood Cemetery making a firm commitment to protect and maintain it.

The Macoun Marsh project encourages students to study the marsh over different seasons. They are taught to record scientific observations in journals, identify and study the different species found, and learn the fundamentals of ecology. They also design, construct, install and maintain bird feeders at the site. Under Michael's careful instruction, the Educarium students have documented nearly 900 species at the marsh.

The project has grown beyond their wildest expectations. Funding to continue with studies and enhancements has been obtained from a variety of sources including the Wetland Habitat Fund and the City of Ottawa. In conjunction with the Beechwood Cemetery Foundation, plans are underway for habitat enhancement, a boardwalk, and an outdoor classroom in spring 2006. The students continue to keep nature journals and will present this work at various venues around the city over the coming year. Michael invited the neighbouring Jean Vanier Catholic School to join his students on the project, and in May 2006 both schools sent representatives to Göteborg, Sweden, for the Volvo Adventure International contest for natural history projects.

Michael's inspired teaching guarantees that his students will continue to be engaged by the world of nature, and so it is for this most important work, that OFNC is pleased to present Michael Léveillé with the Mary Stuart Education Award for 2005. 